\title{
Trends in the biotech literature
}

\section{Stacy Lawrence}

The US remains the most productive country in terms of biotech-related papers, with MIT and Harvard the leading universities. But numbers of papers from the EU surpassed the US last year (with Germany and the UK ahead of most EU countries); elsewhere, Korea, China and

\section{US universities publishing biotech}

In the US, MIT and Harvard publish most of the highly-cited biotech papers.

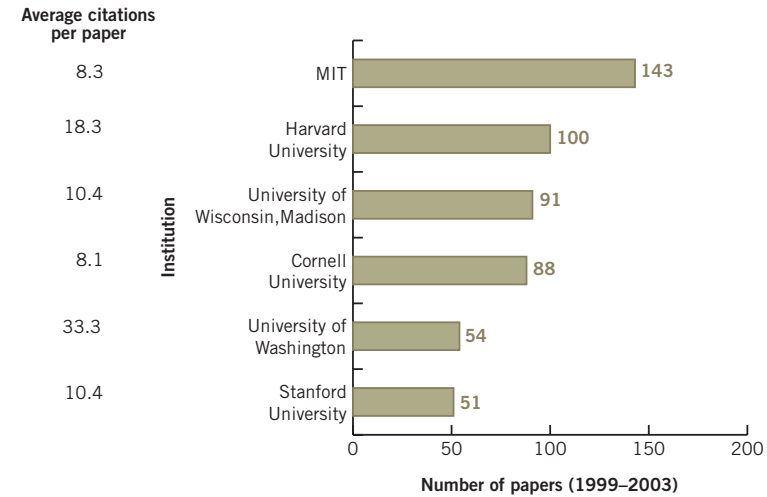

Source: In-Cites, University Science Indicators

Japan also publish frequently. Overall, the number of biotech papers in NCBI's PubMed has more than doubled in the past decade $(1,890$ in $1994 ; 5,913$ in 2004). Research in fields such as RNAi and proteomics appears particularly fertile.

\section{Number of biotech journal articles by country}

Papers originating from EU countries surpassed the US in 2004.

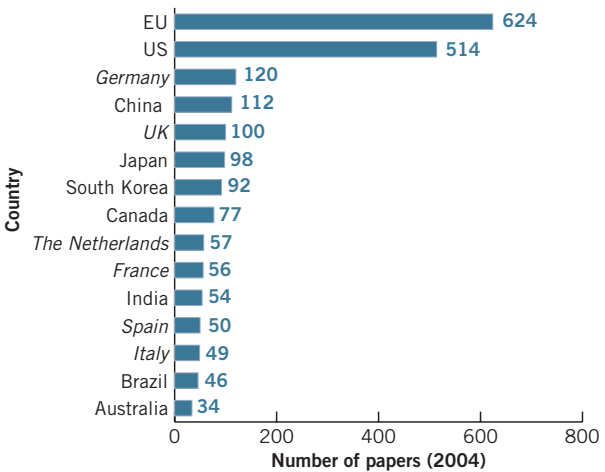

Source: PubMed search for papers containing term 'biotechnology'

\section{Top cited paper by field}

\section{Field Author}

RNAi

Kamath, R.S. et al.

Title

Citation

Systematic functional analysis of the Caenorhabditis elegans genome using RNAi.

Nature 421, 231-237 (2003)

Gene therapy Hacein- Bey-Abina, LMO2-associated clonal T cell proliferation in two patients after gene therapy for SCID-X2.

ES cells Chambers, I. et al Functional expression cloning of Nanog, a pluripotency sustaining factor in embryonic stem cells.

Wu, X.Y. etal. Immunofluorescent labeling of cancer marker Her2 and other cellular targets with

Science 302, 415--419 (2003)

cited

Fluorescence

imaging

semiconductor quantum dots.

Proteomics Foster, L.J. et al Unbiased quantitative proteomics of lipid rafts reveals high specificity for signaling factors.

Nuclear transfer Hubner, K. et al.

Derivation of oocytes from mouse embryonic stem cells.

DNA vaccines McConkey, S.J. et al. Enhanced T-cell immunogenicity of plasmid DNA vaccines boosted by recombinant modified vaccinia virus

$\begin{array}{lll}\text { Biosensors } & \text { Looger, L.L. et al. } & \text { Computational design of receptor and sensor proteins with novel functions. } \\ \text { Environmental } & \text { Methe, B.A. et al. } & \text { Genome of Geobacter sulfurreducens: metal reduction in subsurface environments. }\end{array}$

biotechnology

Overexpression of a plasma membrane $\mathrm{Na}+/ \mathrm{H}+$ antiporter gene improves salt tolerance in Arabidopsis thaliana.

Cell 113, 643-655 (2003)

Nat. Biotechnol. 21, 41-46 (2003) 101

PNAS 100, 5813--5818 (2003) 81

Science 300, 1251-1256 (2003) 78

Nat. Med. 9, 33-39 (2003) 67

Nature 423, 185-190 (2003) 66

Science 302, 1967-1969 (2003) 29

Plant biotechnology Shi, H.Z. et al. 8

\section{Historical trends in biotech fields}

RNAi, proteomics and nanotech have seen explosive growth recently.

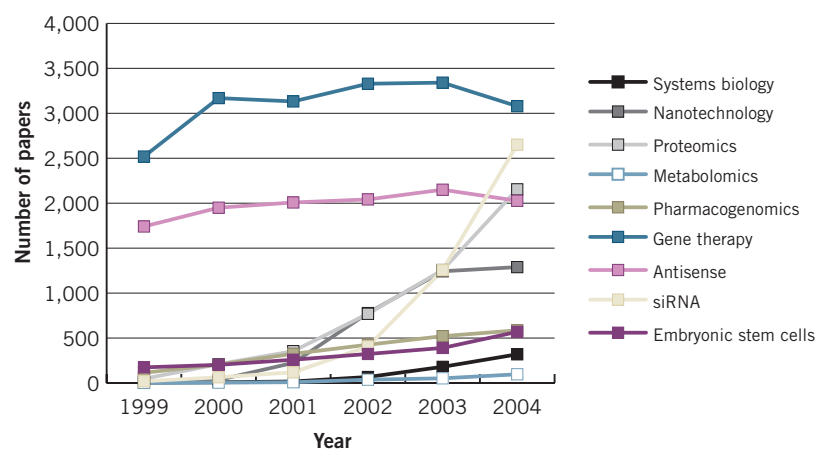

Source: Data from NCBI's PubMed using fields (e.g., proteomics) as search term

\section{Biotech journal impact}

\begin{tabular}{lc} 
Primary research journal & Impact factor \\
Nature Biotechnology & 17.7 \\
Genome Research & 9.6 \\
Molecular and Cellular Proteomics & 8.3 \\
Bioinformatics & 6.7 \\
Molecular Therapy & 6.1 \\
Pharmacogenetics & 5.9 \\
Stem Cells & 5.8 \\
Gene Therapy & 5.3 \\
Human Gene Therapy & 5.0 \\
Review journal & \\
\hline Nature Reviews Drug Discovery & 17.7 \\
Annual Review of Biomedical Engineering & 7.9 \\
Trends in Biotechnology & 7.5 \\
Current Opinion in Biotechnology & 6.9
\end{tabular}

Source: ISI categories Biotechnology \& Applied Microbiology; Engineering, Biomedical 